\title{
Awareness and Practices Regarding Health Promotional Measures of Infant among Mother in Kathmandu, Nepal
}

\author{
Ashru Hira Baral ${ }^{1}$, Jamuna Bhattarai ${ }^{2}$ \\ Lecturer, Department of Nursing, Nobel College, Kathmandu, Nepal \\ Lecturer, Department of Community Health Nursing, Birgunj Nursing Campus, Institute of Medicine, Tribhuvan University
}

(Corresponding Author)

\begin{abstract}
Infancy is a major life transition for the baby and parents. Mothers are considered as the primary care taker of infant meeting their psychological and physiological need. Hence the study aims to assess the awareness and practice regarding health promotional measure of infant among mothers at Maternal and Child Health Clinic of Family Welfare Centre Chhetrapati, Kathmandu. The study was conducted by using descriptive cross sectional study design. A total of 191 mothers having one month to twelve months infants were selected by using non-probability purposive sampling technique. Data were collected by using pre tested structured interview schedule in Nepali version. The obtaining data were analysed by using SPSS version 16 by descriptive and inferential statistics. The findings of the study revealed that majority of mothers $(88.0 \%)$ had poor level of awareness and more than two third of mothers (68.6\%) had poor level of Practice. None of the socio- demographic variables were significantly associated with knowledge and practice. Therefore, the study concluded that there was poor awareness and practice regarding health promotional measures of infant among mothers. There is a need for the health personnel for the awareness and practice to provide information, education and communication through conduction of educational programme to provide appropriate and anticipatory guidance for mothers of Maternal and Child Health Clinic.
\end{abstract}

Keywords: Awareness, Practice, Mother, Kathmandu

\section{Introduction}

Children are the foundation of the future, which determines the socioeconomic basis of the country, thus ensuring their healthy growth and development ought to be a prime concern of all communities, societies, and government. The infants are dependent and susceptible for permanent effects of risky and vulnerable activities hence the need of health maintenance has greater importance. Under ideal circumstances, a family, community and society can adequately provide most of the environmental components for adequate health maintenance that encourage and facilitate development of health and promote the health. The most common causes of death of the infants are diarrhea and respiratory infection. The problems are related to inadequate breast Feeding, lack of knowledge in complimentary feeding and lack of immunization. Mother can prevent or minimize these problems by proper care of infants. [1]

The infants are dependent and susceptible for permanent effects of risky and vulnerable activities hence the need of health maintenance has greater importance. Under ideal circumstances, a family, community and society can adequately provide most of the environmental components for adequate health maintenance that encourage and facilitate development of health and promote the health. For effective health promotion family resources only can be limited and minimal hence acquiring the health care facilities and services are essential to enhance, improve and promote the health of the infant.[2]

According to World Health Organization, health promotion is the process of enabling people to increase control over and to improve their health. It moves beyond a focus on individual behavior towards a wide range of social and environmental interventions. [3]

By fulfillment of physical and psychological needs through essential neonatal care breast feeding, weaning, immunization, safety precautation for prevention of accidents, play stimulation and health supervision at regular interval the health promotion of the infants can be achieved. The emotional social needs can be fulfilled by parents through interaction with infant, building trust relationship through love, security and satisfaction. Mother is the significant person for the promotion of psychosocial development. Health care providers should assist the parents to make decisions and to take care of their children according to their individual child's needs.[4]

The poor economic condition, low availability of food and low literacy rate of the female are side lying causes of malnutrition problem of children. Due to poverty they cannot get to provide enough nutritive food very low production or unavailability of the food also could not meet nutritional requirement. On other hand illiterate mother are not aware of importance of breastfeeding as well as supplementary feeding.[5]

According to the Save the Children, "Healthy baby for healthy nation" was the theme of the $9^{\text {th }}$ national nursing conference. If they get proper attention good care and have better today, they will certainly head the future. In fact infant period is most delicate period of life and needs special care by mother and health personnel.[5] The major components

Volume 9 Issue 7, July 2020

www.ijsr.net

Licensed Under Creative Commons Attribution CC BY 


\section{International Journal of Science and Research (IJSR) \\ ISSN: 2319-7064}

ResearchGate Impact Factor (2018): 0.28 | SJIF (2019): 7.583

of the health promotion of infant are breastfeeding, complementary feeding, immunization and accident. [6]

As stated in the (Global Strategy on Infant and Young Child Feeding) breastfeeding is an unequalled way of providing ideal food for the healthy growth and development of infants. It is also an integral part of the reproductive process with important implications for the health of mothers. As a global public health recommendation, infants should be exclusively breastfed for the first six months of life to achieve optimal growth, development and health [3].

When breast milk is no longer enough to meet the nutritional needs of the infant, complementary foods should be added to the diet of the child. The transition from exclusive breastfeeding to family foods, referred to as complementary feeding, typically covers the period from 6 to 18-24 months of age, and is a very vulnerable period. It is the time when malnutrition starts in many infants, contributing significantly to the high prevalence of malnutrition in children under five years of age world-wide. WHO estimates that 2 out of 5 children are stunted in low-income countries [3].

Immunization is a proven tool for controlling and eliminating life-threatening infectious diseases and is estimated to avert between 2 and 3 million deaths each year. It is one of the most cost-effective health investments, with proven strategies that make it accessible to even the most hard-to-reach and vulnerable populations. It has clearly defined target groups, it can be delivered effectively through outreach activities, and vaccination does not require any major lifestyle change [3].

The Central for disease control Childhood Injury reported patterns of unintentional injuries among 0-19 year olds in the united states, 2000 - 2006 uses data from the national vital statistics systems and the national electronic injury surveillance system all injury program to provide an overview of unintentional injuries related to drowning, falls, fires or burns, poisoning, suffocation, and transportationrelated injuries among others, during the period 2000 to 2006. Results are presented by age group and sex, as well as the geographic distribution of injury death rates by stat [7].

The most common causes of death of the infants are diarrhea and respiratory infection. The problems are related to inadequate breast Feeding, lack of knowledge in complimentary feeding and lack of immunization. The other most common cause of death is home accident. Mother can prevent or minimize these problems by proper care of infants. Infant mortality rate (IMR) of the world is 36.58/1000 live births, IMR of United State of America 5.80, Japan 2, China 12.20, Bhutan 33.90, Nepal 28.90, India 40.50 and Pakistan 53.90/1000 live births [8].

It is estimated that nearly 50,000 infant dies each year in Nepal (MOH, 2006). The trend of infant mortality rate (IMR) of Nepal in the year 2006 is 48 per 1000 live birth, in the year 2011 is 46 per 1000 live birth and in the year 2016 is 32 per 1000 live birth. Eighty-two percent of all deaths among children under age 5 in Nepal take place before a child's first birthday, with $54 \%$ occurring during the first month of life [9].
Death during the neonatal period may be greatly influenced by local beliefs and practices, which determine the type of care given to the child at home as $(81 \%)$ of women deliver at home and $(50 \%)$, deliver with the assistant of friends or relatives. Only (9\%) of home delivery kits are used. There are certain socio-cultural and traditional practices, local beliefs and taboos which influences the quality new born care at home. It is therefore necessary for all health care workers to be aware of traditional practices and beliefs to neonatal care [1].

In infancy $90 \%$ brain growth and $50 \%$ physical growth occur. Birth weight is usually double by 5 months age and tripled by one year. There is a critical or sensitive periods in growth and development such as brain cells are present by the end of first year although their size and complexity will increase maturation of brain stem and spinal cord. Infancy is the period of trust versus mistrust according to Erick Erickson. It is the time of foundation of basic trust. Strong parent child attachment and positive parenting, resulting in better social and emotional wellbeing among children [6].

The child health status depends upon the mother's knowledge, attitude and practice regarding knowledge of health promotion because mothers hand is the first for the child to care, the main responsibility of baby care first goes to mother and family, so it is important to assess awareness and practice of mother regarding health promotion of infant and to give them health education in order to reduce infant morbidity and mortality [10]

Hence to maintain the proper health status of infant, proper infant health promotion is necessary. Mother has the main parenting role of her infant rather than father, as she spends almost all time with her infant. Health promotion of infant depends upon the level of knowledge, awareness and practice of mother. Thus the researcher is highly motivated to conduct research on this topic.

The general objective of the study was to find out the awareness and practices regarding health promotional measures of infant among the mothers attending a Maternal and Child Health (MCH) clinics in Kathmandu. Specific objectives were to assess the level of awareness regarding health promotional measures of infant.To identify the level of practice regarding health promotional measure of infant. To measure the association between level of awareness of mother regarding health promotional measures of infant with selected demographic variables.To examine the association between level of practices of mother regarding health promotional measures of infants with selected demographic variables.To identify the relationship between awareness and practice of mother regarding health promotional measure of infant. The finding of the study might be useful to explore the awareness and practice of mothers which can be basis for planning health education in various level of health facility to promote health promotional of infant.

\section{Methodology}

Descriptive correlational study design was used for this study to find out awareness and practice regarding health promotional measure of infant among mothers at Maternal

Volume 9 Issue 7, July 2020 www.ijsr.net 


\section{International Journal of Science and Research (IJSR) \\ ISSN: 2319-7064}

ResearchGate Impact Factor (2018): 0.28 | SJIF (2019): 7.583

and Child Health Clinic (MCH) of Family Welfare Center Chhetrapati, Kathmandu, which is a melting pot of various cultural groups, ethnicities, races, languages and religions which is located in the hills of Bagmati Zone, central development region, Nepal. The populations of this study were all the mothers having child aged one month to 12 months attending Maternal and Child Health Clinic of Family Welfare Centre Chhetraparti, Kathmandu, Non probability purposive sampling was done among 191 sample. The sample size (n) was determined for $95 \%$ confidence level and of $5 \%$ confidence limit. The percentage of women having the knowledge of breastfeeding as per study done on Kathmandu was $87 \%$ [11]. Calculated sample size was 173.72 approximately 174 To minimize the non - response error, $10 \%$ sample was added on it. Therefore required sample size was 191. For this study researcher herself selected only those people who fulfill the criteria as well as particular subjects that are typical and representative part of population. Total 191 mothers child age one month to twelve months attending 'Maternal and Child Health Clinic was selected. The interview schedule of the study was divided into three parts. In order to measure the awareness and practice variables of the research, a set of structured awareness interview schedule and structured practice interview schedule was constructed by the researcher.

Regarding tool, Question related to awareness regarding health promotional measure of infant, which comprised of 24 questions. It consisted of four sub scales which comprised of awareness regarding breastfeeding, awareness regarding complimentary feeding, awareness regarding immunization and awareness regarding prevention of accidents each consisting 8,6,6,4 items respectively. In each subscale there were single responses as well as multiple response items. So the score of each subscale were 12, 8, 12, 6 respectively. The total score for this section was 38. The awareness score was categorized as: Good Awareness: $\geq$ $50 \%$ of total score and Poor awareness $<50 \%$ total score.

Question related to practice regarding health promotional measure of infant, which comprised of 18 questions. It consisted of four sub scales which comprised of practice regarding breastfeeding, practice regarding complimentary feeding, practice regarding immunization and practice regarding prevention of accidents each consisting of $6,5,3,4$ items respectively. In the subscale, practice regarding breastfeeding and practice regarding immunization single response items were only included, whereas in the subscale practice regarding complementary feeding and practice regarding prevention of accidents single response as well as multiple response items were included,. So the score in each subscale were $6,7,3,6$ respectively. The total score of this section was 22. The practice score was categorized as; Good Practice: $\geq 50 \%$ of total score and Poor practice $<50 \%$ total score.

The content validity of the instrument was established by seeking opinion of 9 experts from the field of child health, research advisor, subject matter specialist, statistician and valuable suggestions from the colleagues. The instrument was translated to Nepali and further translation to English was done and verified by language expert. Pretesting of the tool was done among 19 mothers in similar setting who fulfills the inclusion criteria and necessary modification was done. Written permission was obtained from the research committee of National Medical College Institutional Research Committee Birgunj, Nepal. Data was collected after getting ethical clearance from Institutional Review committee and administrative permission from the head of $\mathrm{MCH}$ clinic of Chhetrapati. Written informed consent was obtained from the mothers to ensure the right of subjects prior to involve them in the study. Mothers who meet the inclusion criteria were identified and explained the objectives of the study and assure for the confidentiality by disclosing the information and that information was used only for research purpose and mother were informed about the duration of interview. Mothers were informed that they may refuse to participate in the study at any time if they wish. The information was collected by researcher herself by using structured interview schedule in Nepali version from June 20, 2017 to July 15, 2017 and approximately it took 25 minutes to interview each mother.

\section{Findings}

Table 1: Distribution of Mothers according to Age, Religion, Place of residence and Ethnic group, $n=191$

\begin{tabular}{|c|c|c|}
\hline Characteristics & Number & Percentage \\
\hline \multicolumn{3}{|l|}{ Age (in years) } \\
\hline Below 20 & 22 & 11.5 \\
\hline 20 to 25 & 60 & 31.4 \\
\hline 26 to 30 & 63 & 33 \\
\hline Above 31 & 46 & 24.1 \\
\hline \multicolumn{3}{|l|}{ Mean $\pm S D, 26.74 \pm 4.91 s$} \\
\hline \multicolumn{3}{|l|}{ Religion } \\
\hline \begin{tabular}{l|l} 
Hinduism \\
\end{tabular} & 129 & 67.5 \\
\hline Christianity & 29 & 15.2 \\
\hline Buddhism & 27 & 13.8 \\
\hline Islam & 6 & 3.1 \\
\hline \multicolumn{3}{|l|}{ Ethnic Group } \\
\hline Janajati & 87 & 45.5 \\
\hline Bramhins & 37 & 19.4 \\
\hline Terai Caste (Madhesi) & 31 & 16.2 \\
\hline Dalit & 23 & 12 \\
\hline Muslim & 7 & 3.7 \\
\hline Others* & 6 & 3.1 \\
\hline
\end{tabular}

Others*: Yogi, Giri

Table 1 presents the socio demographic characteristics of the mothers where one third $(33 \%)$ of mothers were of age group 26-30. More than two third (67.5\%) mothers belonged to Hindu religion and almost half $(45.5 \%)$ belonged to Janajati ethnicity.

Table 2: Distribution of the Mothers according to Education, Occupation, Monthly Income, Economic Status, Types of Family, No of living child and Source of Information, $\mathrm{n}=191$

\begin{tabular}{|l|c|c|}
\hline Characteristics & Number & Percentage \\
\hline Education & & \\
\hline Cannot Read and Write & 12 & 6.3 \\
\hline Can Read and Write & 23 & 12.0 \\
\hline Primary Education & 40 & 20.9 \\
\hline Secondary Level & 55 & 28.06 \\
\hline Higher secondary or above & 61 & 32.9 \\
\hline
\end{tabular}

\section{Volume 9 Issue 7, July 2020 www.ijsr.net}


International Journal of Science and Research (IJSR)

ISSN: 2319-7064

ResearchGate Impact Factor (2018): 0.28 | SJIF (2019): 7.583

\begin{tabular}{|c|c|c|}
\hline \multicolumn{3}{|l|}{ Occupation } \\
\hline Homemaker & 108 & 56.5 \\
\hline Agriculture & 23 & 12.0 \\
\hline Service & 27 & 14.1 \\
\hline Business & 30 & 15.7 \\
\hline Labor & 3 & 1.6 \\
\hline \multicolumn{3}{|c|}{ Economic status (food sufficiency) } \\
\hline Less than 3 months & 21 & 11.0 \\
\hline Upto 6 months & 70 & 36.6 \\
\hline Upto 12 months & 67 & 35.1 \\
\hline More than 12 months & 33 & 17.3 \\
\hline \multicolumn{3}{|l|}{ Types of family } \\
\hline Nuclear & 99 & 51.8 \\
\hline Joint & 86 & 45.0 \\
\hline Extended Family & 6 & 3.1 \\
\hline \multicolumn{3}{|l|}{ No of living children } \\
\hline 1 & 87 & 45.5 \\
\hline 2 & 79 & 41.4 \\
\hline 3 & 24 & 12.6 \\
\hline 4 & 1 & 0.5 \\
\hline \multicolumn{3}{|l|}{ Source of information } \\
\hline Health Personnel & 138 & 72.3 \\
\hline Radio/TV & 33 & 17.3 \\
\hline Family \& Friends & 17 & 8.9 \\
\hline News paper/ internet & 3 & 1.6 \\
\hline
\end{tabular}

$\mathrm{n}=19$

Table 3 shows awareness of mothers regarding breastfeeding. Among them majority of the mothers (93.7\%) had mentioned correct answer regarding meaning of breastfeeding. Regarding best nutrition for $<6$ month baby most of them $(71.2 \%)$ mothers mentioned the breast feeding. All $(100 \%)$ mothers correctly answer regarding necessity to feed colostrums to child which was good for babies. Almost one third $(35.6 \%)$ mothers had answered correctly regarding duration of exclusive breastfeeding. Similarly very few (11\%) mothers answered correctly regarding duration of breastfeeding with complimentary feeding. More than half of them $(59.2 \%)$ mothers mentioned colostrums is important to prevent disease to their infants. Similarly, regarding benefit of the breastfeeding, more than half $(62.3 \%)$ mothers answered it provides immunity to their infants

Table 4: Awareness of Mothers Regarding Complementary Feeding

\begin{tabular}{|c|c|c|}
\hline \multirow{2}{*}{ Items } & \multicolumn{2}{|c|}{ Correct response } \\
\hline & Number & Percentage \\
\hline \multicolumn{3}{|l|}{ Meaning of complimentary feeding } \\
\hline $\begin{array}{l}\text { Transition from exclusive breastfeeding to } \\
\text { family food }\end{array}$ & 51 & 26.7 \\
\hline \multicolumn{3}{|l|}{ Time to start complimentary feeding } \\
\hline From 6 months ${ }^{\#}$ & 57 & 29.8 \\
\hline \multicolumn{3}{|l|}{ Food introduce for complimentary feeding } \\
\hline Mashed cereals $^{\#}$ & 91 & 47.6 \\
\hline \multicolumn{3}{|l|}{$\begin{array}{l}\text { Frequency of complimentary feeding } \\
\text { (baby of 6-8 months) }\end{array}$} \\
\hline Two to three times ${ }^{\#}$ & 58 & 30.4 \\
\hline \multicolumn{3}{|l|}{$\begin{array}{l}\text { Frequency of complimentary feeding } \\
\text { (baby of 9-12 months) }\end{array}$} \\
\hline 3 to 4 times ${ }^{\#}$ & 37 & 19.4 \\
\hline \multicolumn{3}{|l|}{ Advantages of complimentary feeding* } \\
\hline Maintain weight for height & 81 & 42.4 \\
\hline Overall growth and development & 74 & 38.7 \\
\hline Bring proper weight & 46 & 24.1 \\
\hline
\end{tabular}

Table 3: Awareness of Mothers Regarding Breastfeeding, $\mathrm{n}=191$

\begin{tabular}{|c|c|c|}
\hline \multirow{2}{*}{ Items } & \multicolumn{2}{|c|}{ Correct Response } \\
\hline & Number & Percentage \\
\hline \multicolumn{3}{|l|}{ Meaning of breast feeding } \\
\hline Feeding infant only breast milk ${ }^{\#}$ & 179 & 93.7 \\
\hline \multicolumn{3}{|l|}{ Best nutrition for baby (<6 months) } \\
\hline Only breastfeeding ${ }^{\#}$ & 136 & 71.2 \\
\hline \multicolumn{3}{|l|}{ Breast feeding start time after delivery } \\
\hline Within half to one hour after birth ${ }^{\#}$ & 47 & 24.6 \\
\hline \multicolumn{3}{|l|}{ Necessity to feed colostrums to child } \\
\hline Yes $^{\#}$ & 191 & 100.0 \\
\hline \multicolumn{3}{|l|}{ Duration of exclusive breast feeding } \\
\hline Up to 6 months ${ }^{\#}$ & 68 & 35.6 \\
\hline \multicolumn{3}{|l|}{ Breast feeding continuation duration } \\
\hline Up to 2 years $^{\#}$ & 21 & 11.0 \\
\hline \multicolumn{3}{|l|}{ Advantages of colostrums feeding* } \\
\hline It is nutritious & 70 & 36.6 \\
\hline It prevent from disease & 113 & 59.2 \\
\hline It make baby strong & 38 & 19.9 \\
\hline \multicolumn{3}{|l|}{ Benefits of breastfeeding* } \\
\hline $\begin{array}{l}\text { Breastfeeding is the sufficient nutrition for } \\
\text { newborn baby }\end{array}$ & 63 & 33.0 \\
\hline $\begin{array}{l}\text { It strength the bond between mothers and } \\
\text { baby }\end{array}$ & 57 & 29.8 \\
\hline It provide immunity to the infants & 119 & 62.3 \\
\hline
\end{tabular}

Table 4 represents that $(26.7 \%)$ mothers answered correctly regarding meaning of complimentary feeding. Similarly regarding time to start complimentary feeding (29.8\%) mothers mentioned from 6 months. Only $40.3 \%$ introduced solid food as its means. Only (47.6\%) mothers started complimentary food using mashed cereals as its type. Only $30.2 \%$ of the mothers answered correctly regarding frequency of complimentary feeding for six to 8 months. Similarly (19.4\%) mothers answered correctly regarding frequency of food for babies of 9-12 months.

Table 5: Awareness 0f Mothers regarding Immunization, $\mathrm{n}=191$

\begin{tabular}{|c|c|c|}
\hline \multirow{2}{*}{ Items } & \multicolumn{2}{|c|}{ Correct Response } \\
\cline { 2 - 3 } & Number & Percent \\
\hline $\begin{array}{c}\text { Immunization provided for babies (<1 } \\
\text { year baby) }\end{array}$ & & \\
\hline BCG,DPT,Heb B, Hib,Polio \& measles\# & 41 & 21.5 \\
\hline $\begin{array}{c}\text { Time to start DPT vaccine for newborn } \\
\text { baby }\end{array}$ & & \\
\hline Within 45 days\# & 74 & 38.7 \\
\hline $\begin{array}{c}\text { Time interval for DPT+Hep B+ Hib \& } \\
\text { Polio }\end{array}$ & & \\
\hline 1 month\# & 126 & 66.0 \\
\hline
\end{tabular}

Volume 9 Issue 7, July 2020 www.ijsr.net

Licensed Under Creative Commons Attribution CC BY 


\section{International Journal of Science and Research (IJSR) \\ ISSN: 2319-7064}

ResearchGate Impact Factor (2018): 0.28 | SJIF (2019): 7.583

\begin{tabular}{|c|c|c|}
\hline Meaning of immunization* & & \\
\hline Gain immunity against diseases & 62 & 32.5 \\
\hline Gain protection from different diseases & 102 & 53.4 \\
\hline Administration of vaccine & 40 & 20.9 \\
\hline Advantages of immunization* & & \\
\hline Prevention from all childhood disease & 71 & 37.2 \\
\hline Prevention from childhood fatal disease & 69 & 36.1 \\
\hline To make baby strong & 57 & 29.8 \\
\hline $\begin{array}{c}\text { Common side effect of intramuscular } \\
\text { injection* }\end{array}$ & & \\
\hline Pain & 58 & 30.4 \\
\hline Fever & 121 & 63.4 \\
\hline Swelling & 27 & 14.1 \\
\hline
\end{tabular}

\# correct response *multiple response

Table 5 represents the awareness of mothers regarding immunization. Only $21.5 \%$ of the mothers correctly answered about immunization provided for $(<1$ year baby). Similarly regarding time to start DPT vaccine for new born (38.7\%) mothers mentioned within 45 days. Regarding time interval for DPT,Hep B,Hib and polio (66\%) mothers answered correctly. Likewise regarding meaning of immunization (53.4\%) mothers mentioned it gain protection from different disease. Similarly regarding advantages of immunization (37.2\%) mothers answered it prevent from all childhood disease. Similarly regarding common side effect of intramuscular injection most of the mothers (63\%) mentioned fever.

Table 6: Awareness of Mothers Regarding Prevention of Accident, $\mathrm{n}=191$

\begin{tabular}{|c|c|c|}
\hline Items & \multicolumn{2}{|c|}{ Correct Response } \\
\cline { 2 - 3 } & Number & Percentage \\
\hline $\begin{array}{c}\text { Common home accident for baby (less } \\
\text { than 1 year) }\end{array}$ & & \\
\hline Fall, ingestion, injury, burn* & 63 & 33 \\
\hline $\begin{array}{c}\text { Prevention of ingestion injury among } \\
\text { infants }\end{array}$ & & \\
\hline $\begin{array}{c}\text { Avoid small piece of object in toys and other } \\
\text { environment* }\end{array}$ & 81 & 42.4 \\
\hline $\begin{array}{c}\text { Developmental facts leading to ingestion } \\
\text { injury to infant }\end{array}$ & & \\
\hline Keeping everything in mouth* & 48 & 25.1 \\
\hline Prevention of fall accidents among infant* & & \\
\hline Keep bedside railing & 46 & 24.1 \\
\hline Do not leave the child alone & 116 & 60.7 \\
\hline Do not take the child to high places & 52 & 27.2 \\
* correct response *multiple response & & \\
\hline
\end{tabular}

Table 6 shows awareness of mothers regarding common home accidents one third (33\%) mothers answered fall ingestion injury and burn as common home accidents for $<1$ years baby. Similarly $(42.4 \%)$ mothers mentioned avoiding small piece of object in toys and other environment for prevention of ingestion injury among infants. Only (25.1\%) mothers mentioned keeping everything in mouth caused by developmental factors leading to ingestion injury to infant. Similarly more than half $(60.7 \%)$ mothers reveled do not leave the child alone for prevention of fall accidents among infant.
Table 7: Practices of Mothers Regarding Breastfeeding, $\mathrm{n}=191$

\begin{tabular}{|c|c|c|}
\hline Items & \multicolumn{2}{|c|}{ Number|Percent } \\
\hline \multicolumn{3}{|c|}{ 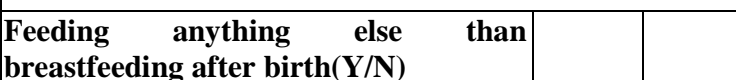 } \\
\hline Yes & 27 & 14.1 \\
\hline $\mathrm{No}^{\#}$ & 164 & 85.9 \\
\hline \multicolumn{3}{|l|}{ Pre-lacteal feeding after birth $(\mathrm{n}=27)$} \\
\hline Honey & 20 & 74.07 \\
\hline Glucose water & 1 & 3.70 \\
\hline Herbs water & 6 & 22.22 \\
\hline \multicolumn{3}{|l|}{ Feeding colostrums to baby } \\
\hline Yes $^{\#}$ & 191 & 100.0 \\
\hline \multicolumn{3}{|c|}{$\begin{array}{l}\text { Time of start of breastfeeding after } \\
\text { birth }\end{array}$} \\
\hline Half an hour to one hour after birth ${ }^{\#}$ & 66 & 34.6 \\
\hline \multicolumn{3}{|c|}{ Exclusive breastfeeding for baby ( $<6$ months) } \\
\hline Yes $^{\#}$ & 129 & 67.5 \\
\hline \multicolumn{3}{|l|}{ Activity after breastfeeding } \\
\hline Do burping ${ }^{\#}$ & 30 & 15.7 \\
\hline \multicolumn{3}{|l|}{ Measures before breastfeeding } \\
\hline Wipe the breast with clean cloth $^{\#}$ & 36 & 18.8 \\
\hline
\end{tabular}

Table 7 declares the practice regarding breastfeeding. Majority $(85.9 \%)$ of mothers didn't fed anything else than breastfeeding. Among the mothers (27) (14.1\%) who fed pre- lacteal food $(74.07 \%)$ fed honey, $(3.70 \%)$ fed glucose water and $(22.22 \%)$ fed herbs water. Similarly all mothers (100\%) feed colostrums to their baby. Regarding time of start of breastfeeding after birth $(34.6 \%)$ mothers fed breast milk half an hour to one hour after birth to their babies. Likewise $(67.5 \%)$ mothers provided exclusive breastfeeding for baby (<6 months). Only (15.5\%) mothers do burping to their babies after breastfeeding. Only (18.8\%) mothers mentioned the correct measures before breastfeeding.

Table 8: Practices of Mothers Regarding Complimentary Feeding, $\mathrm{n}=85$

\begin{tabular}{|c|c|c|}
\hline \multirow{2}{*}{ Items } & \multicolumn{2}{|c|}{ Correct response } \\
\hline & Number & Percentage \\
\hline \multicolumn{3}{|l|}{ Starting age of complimentary feeding } \\
\hline From 6 months ${ }^{\#}$ & 41 & 21.5 \\
\hline \multicolumn{3}{|c|}{ Start up food for complimentary feeding } \\
\hline Mashed cereals ${ }^{\#}$ & 52 & 27.2 \\
\hline \multicolumn{3}{|c|}{ Continuation of breast feeding with complimentary feeding $(\mathrm{Y} / \mathrm{N})$} \\
\hline Yes $^{\#}$ & 81 & 42.4 \\
\hline \multicolumn{3}{|c|}{ Number of food items introduced at once to baby } \\
\hline Only one food ${ }^{\#}$ & 76 & 39.8 \\
\hline \multicolumn{3}{|l|}{ Measure taken before giving food* } \\
\hline Wash hand with soap and waters & 69 & 36.1 \\
\hline Wash utensils with boiled water & 16 & 8.4 \\
\hline Taste food before feeding & 12 & 6.1 \\
\hline
\end{tabular}
(Less than 6 months excluded) ${ }^{\#}$ Correct response *Multiple response

Table 8 highlights practice of mothers regarding complimentary feeding. only $(21.5 \%)$ mothers answered correctly about starting age of complimentary feeding. Similarly (27.2\%) mothers answered correctly about start up food for complimentary feeding. Only (42.4\%) mothers answered correctly about continuation of breast feeding with complimentary feeding. Similarly (39.8\%) mothers 


\section{International Journal of Science and Research (IJSR) \\ ISSN: 2319-7064}

ResearchGate Impact Factor (2018): 0.28 | SJIF (2019): 7.583

answered correctly about number of food items introduced at once to baby. Only (36.1\%) mothers do correct measure before giving food to their baby.

Table 9: Practices of Mothers Regarding Immunization and Prevention of Accidents, $n=191$

\begin{tabular}{|c|c|c|}
\hline \multirow{2}{*}{ Items } & \multicolumn{2}{|c|}{ Correct Response } \\
\hline & Number & Percentage \\
\hline \multicolumn{3}{|l|}{ Practice regarding Immunization } \\
\hline \multicolumn{3}{|l|}{$\begin{array}{l}\text { Immunized baby acc to National } \\
\text { Immunization Schedule (Y/N) }\end{array}$} \\
\hline Yes $^{\#}$ & 191 & 100.0 \\
\hline \multicolumn{3}{|c|}{$\begin{array}{l}\text { Action taken at home for baby with fever after } \\
\text { vaccination }\end{array}$} \\
\hline Bring hospital $^{\#}$ & 71 & 37.2 \\
\hline \multicolumn{3}{|c|}{$\begin{array}{l}\text { Action taken for baby with side effects after } \\
\text { vaccination }\end{array}$} \\
\hline Take to the hospital $^{\#}$ & 136 & 71.2 \\
\hline \multicolumn{3}{|l|}{$\begin{array}{llll}\begin{array}{l}\text { Practices } \\
\text { Accidents }\end{array} & \text { regarding } & \text { Prevention of } \\
\end{array}$} \\
\hline \multicolumn{3}{|l|}{$\begin{array}{l}\text { Action taken for child suffering from } \\
\text { burn }\end{array}$} \\
\hline Keep part on the water ${ }^{\#}$ & 67 & 35.1 \\
\hline \multicolumn{3}{|l|}{$\begin{array}{l}\text { Action taken to prevent ingestion injury } \\
\text { among infants }\end{array}$} \\
\hline $\begin{array}{l}\text { Avoid small piece of toys and other } \\
\text { environment }\end{array}$ & 86 & 45.0 \\
\hline \multicolumn{3}{|l|}{$\begin{array}{l}\text { Precautions to be provided when babies } \\
\text { are playing }\end{array}$} \\
\hline Provide safety play materials ${ }^{\#}$ & 160 & 81.6 \\
\hline \multicolumn{3}{|l|}{$\begin{array}{l}\text { Measure to prevent fall accidents among } \\
\text { infants }\end{array}$} \\
\hline Keep the bedside railing & 56 & 29.9 \\
\hline Do not leave the child alone & 137 & 71.7 \\
\hline Do not take the child to high places & 23 & 12.0 \\
\hline
\end{tabular}

Table 9 reveals practice of mothers regarding immunization and prevention of accidents. All (100\%) mothers immunized their baby according to immunization schedule. However only $(37.2 \%)$ mothers do correct practice with fever after vaccination. Most of the $(71.2 \%)$ mothers answered correctly about action taken for baby with side affects after vaccination. Similarly only $(35.1 \%)$ mothers do correct practice when child suffering from burn. Only (45.0\%) mothers answered correctly about action taken to prevent ingestion injury among infants. Majority (81.6\%) of mothers take correct precaution when babies are playing. Most $(71.7 \%)$ of mothers do not leave the child alone to prevent fall accidents among infants.

Table 10: Mean Score of Awareness of Mothers' regarding Health Promotional Measures of Infants, $n=191$

\begin{tabular}{|c|c|c|c|}
\hline Subscale of Awareness & $\begin{array}{c}\text { Maximum } \\
\text { possible score }\end{array}$ & Mean \pm SD & Range \\
\hline Breastfeeding & 12 & $5.77 \pm 1.27$ & $3-9$ \\
\hline Complimentary feeding & 8 & $2.59 \pm 1.16$ & $1-6$ \\
\hline Immunization & 12 & $4.43 \pm 1.14$ & $3-8$ \\
\hline Prevention of accident & 6 & $2.12 \pm 1.10$ & $1-6$ \\
\hline Total & $\mathbf{3 8}$ & $\mathbf{2 1 . 5 0} \pm \mathbf{2 . 2 7}$ & $\mathbf{1 0 - 2 8}$ \\
\hline
\end{tabular}

Table 10 illustrates the scoring of awareness of mothers' regarding health promotional measures of infants. Awareness of mothers regarding health promotional measures of infants. contains 4 subscales which are awareness of breastfeeding, awareness of complimentary feeding, awareness of immunization and awareness of prevention of accident each consisting of 12, 8, 12, 6 score respectively. The total maximum obtainable score was 38 and minimum was zero.Regarding awareness of mothers mean obtained score of awareness of breastfeeding subscale by the mothers was 5.77 with standard deviation of 1.27 .

Table 11: Awareness regarding Health Promotional Measures of Infants among Mother

\begin{tabular}{|c|c|c|}
\hline Awareness & Number & Percentage \\
\hline Good awareness $(\geq 19)$ & 23 & 12.0 \\
\hline Poor awareness $(<19)$ & 168 & 88.0 \\
\hline Total & $\mathbf{1 9 1}$ & $\mathbf{1 0 0 . 0}$ \\
\hline
\end{tabular}

Table 11 shows the level of awareness of mothers' regarding health promotional measures of infants. Among 191 mothers only $12.0 \%$ had good level of awareness.

Table 12: Associations between Awareness regarding Health Promotional Measures of Infants among mothers and Socio-demographic Variables, $\mathrm{n}=191$

\begin{tabular}{|c|c|c|c|c|}
\hline \multirow[b]{2}{*}{ Variables } & \multicolumn{2}{|c|}{ Awareness } & \multirow[b]{2}{*}{$\chi^{2}$} & \multirow[b]{2}{*}{$\begin{array}{c}\mathrm{P} \\
\text { value }\end{array}$} \\
\hline & $\begin{array}{c}\text { Poor } \\
\text { Awareness } \\
\mathrm{n}(\%)\end{array}$ & $\begin{array}{c}\text { Good } \\
\text { Awareness } \\
\text { n (\%) }\end{array}$ & & \\
\hline \multicolumn{5}{|c|}{ Age (in years) } \\
\hline Up to 25 & $75(91.5)$ & $7(8.5)$ & \multirow{3}{*}{1.868} & \multirow{3}{*}{0.393} \\
\hline 26 to 30 & $53(84.1)$ & $10(15.9)$ & & \\
\hline Above 31 & $40(87.0)$ & $6(13.0)$ & & \\
\hline \multicolumn{5}{|c|}{ Place of residence } \\
\hline Rural & $102(89.5)$ & $12(10.5)$ & \multirow{2}{*}{0.613} & \multirow{2}{*}{0.434} \\
\hline Urban & $66(85.7)$ & $11(14.3)$ & & \\
\hline \multicolumn{5}{|c|}{ Education Level } \\
\hline Up to primary & $68(90.7)$ & $7(9.3)$ & \multirow{2}{*}{0.855} & \multirow{2}{*}{0.355} \\
\hline More than primary & $100(86.2)$ & $16(13.8)$ & & \\
\hline \multicolumn{5}{|c|}{$\begin{array}{l}\text { Occupation } \\
\end{array}$} \\
\hline Home maker & $96(88.9)$ & $12(11.1)$ & \multirow{2}{*}{0.203} & \multirow{2}{*}{0.652} \\
\hline Working outside & $72(86.7)$ & $11(13.3)$ & & \\
\hline \multicolumn{5}{|l|}{ Economic status } \\
\hline Up to 6 months & $84(92.3)$ & $7(7.7)$ & \multirow[t]{3}{*}{4.154} & \multirow[t]{3}{*}{0.125} \\
\hline Up to 12 months & $58(86.6)$ & $9(13.4)$ & & \\
\hline$>12$ months & $26(78.8)$ & $7(21.2)$ & & \\
\hline \multicolumn{5}{|l|}{ Types of family } \\
\hline Nuclear & $86(86.9)$ & 13(13.1) & \multirow[t]{2}{*}{0.230} & \multirow[t]{2}{*}{0.631} \\
\hline Joint & $82(89.1)$ & $10(10.9)$ & & \\
\hline \multicolumn{5}{|l|}{ Number of children } \\
\hline 1 & $80(92.0)$ & $7(8.0)$ & \multirow[t]{2}{*}{2.409} & \multirow[t]{2}{*}{0.121} \\
\hline 2 or more & $88(84.6)$ & $16(15.4)$ & & \\
\hline
\end{tabular}

Significance at the level 0.05

Table 13 presents association between level of the awareness of mother regarding health promotional measures of infants with socio-demographic variables. The finding of the analysis shows that there was no significant association between awareness level and socio-demographic variables. 


\section{International Journal of Science and Research (IJSR) \\ ISSN: 2319-7064}

ResearchGate Impact Factor (2018): 0.28 | SJIF (2019): 7.583

Table 13: Mean Score of Practice of Mothers' Regarding Health Promotional Measures of Infants among Mothers, $\mathrm{n}=191$

\begin{tabular}{|c|c|c|c|}
\hline Subscale of Practice & $\begin{array}{c}\text { Maximum } \\
\text { possible score }\end{array}$ & Mean \pm SD & Range \\
\hline Breastfeeding & 6 & $2.50 \pm 1.21$ & $1-6$ \\
\hline Complimentary feeding & 7 & $1.82 \pm 2.14$ & $0-7$ \\
\hline Immunization & 3 & $2.08 \pm 0.69$ & $1-3$ \\
\hline Prevention of accident & 6 & $2.74 \pm 0.90$ & $1-6$ \\
\hline Total & 22 & $9.15 \pm 2.71$ & $4-16$ \\
\hline
\end{tabular}

Table 13 presents the scoring of practice of mothers' regarding health promotional measures of infants. Practice of mothers regarding health promotional measures of infants. contains 4 subscales which are practice of breastfeeding, practice of complimentary feeding, practice of immunization and practice of prevention of accident each consisting of $6,7,3,6$ score respectively. The total maximum obtainable scores is 22 and minimum score is 0 . Regarding practice of mothers mean obtained score of practice of prevention of accident subscale by the mothers was 2.7435 with standard deviation of 0.90155 and having range 5 .

Table 14: Practice Regarding Health Promotional Measures of Infants among Mother

\begin{tabular}{|c|c|c|}
\hline Practice & Frequency & Percentage \\
\hline Good practice $(\geq 11)$ & 60 & 31.4 \\
\hline Poor practice $(<11)$ & 131 & 68.6 \\
\hline Total & $\mathbf{1 9 1}$ & $\mathbf{1 0 0 . 0}$ \\
\hline
\end{tabular}

Table 14 shows the level of practice of mothers' regarding health promotional measures of infants. Among 191 mothers less than one third $31.4 \%$ had good level of practice.

Table 15: Associations between Practice regarding Health Promotional Measures of Infants among Mothers and sociodemographic Variables, $\mathrm{n}=191$

\begin{tabular}{|c|c|c|c|c|}
\hline \multirow[b]{2}{*}{ Characteristics } & \multicolumn{2}{|c|}{ Practice } & \multirow[b]{2}{*}{$\chi^{2}$} & \multirow[b]{2}{*}{$\mathrm{P}$ value } \\
\hline & \begin{tabular}{|c} 
Poor practice \\
$\mathrm{n}(\%)$
\end{tabular} & $\begin{array}{c}\text { Good practice } \\
\mathrm{n}(\%)\end{array}$ & & \\
\hline \multicolumn{5}{|l|}{ Age } \\
\hline Up to 25 & $56(68.3)$ & $26(31.7)$ & \multirow{3}{*}{0.482} & \multirow{3}{*}{0.786} \\
\hline 26 to 30 & $45(71.4)$ & $18(28.6)$ & & \\
\hline Above 31 & $30(65.2)$ & $16(34.8)$ & & \\
\hline \multicolumn{5}{|l|}{ Place of residence } \\
\hline Rural & $76(66.7)$ & $38(33.3)$ & \multirow{2}{*}{0.484} & \multirow{2}{*}{0.487} \\
\hline Urban & $55(71.4)$ & $22(28.6)$ & & \\
\hline \multicolumn{5}{|l|}{ Education Level } \\
\hline Up to primary & $51(68.0)$ & $24(32.0)$ & \multirow{2}{*}{0.020} & \multirow{2}{*}{0.888} \\
\hline More than primary & $80(69.0)$ & $36(31.0)$ & & \\
\hline \multicolumn{5}{|l|}{ Occupation } \\
\hline Home maker & $75(69.4)$ & $33(30.6)$ & \multirow{2}{*}{0.0 .085} & \multirow{2}{*}{0.771} \\
\hline Working outside & $56(67.5)$ & $27(32.5)$ & & \\
\hline \multicolumn{5}{|l|}{$\begin{array}{l}\text { Economic status } \\
\text { (Food Sufficiency) }\end{array}$} \\
\hline Up to 6 months & $61(67.0)$ & $30(33.0)$ & \multirow[t]{3}{*}{1.120} & \multirow[t]{3}{*}{0.571} \\
\hline Up to 12 months & $49(73.1)$ & $18(26.9)$ & & \\
\hline$>12$ months & $21(63.6)$ & $12(36.4)$ & & \\
\hline \multicolumn{5}{|l|}{ Types of family } \\
\hline Nuclear & $60(60.5)$ & $39(39.4)$ & \multirow[t]{2}{*}{6.075} & \multirow[t]{2}{*}{0.14} \\
\hline Joint & $71(77.2)$ & $21(22.8)$ & & \\
\hline \multicolumn{5}{|l|}{ Number of children } \\
\hline 1 & $57(65.5)$ & $30(34.5)$ & \multirow[t]{2}{*}{0.6999} & \multirow[t]{2}{*}{0.403} \\
\hline 2 or more & $74(71.2)$ & $30(28.8)$ & & \\
\hline
\end{tabular}

\section{Significance at the level 0.05}

Table 15 shows association between the level of the practice of mothers regarding health promotional measures of infant and socio-demographic variables. The finding of the analysis shows that there was no significant association between practice level and socio-demographic variables.

Table 16: Correlation between Awareness and Practice Score Regarding Health Promotional Measures of Infant among Mothers

\begin{tabular}{|c|c|c|c|}
\hline Correlation & Mean \pm SD & Pearson Correlation(r) & P-value \\
\cline { 1 - 2 } Awareness Score & $21.50 \pm 2.27$ & 0.109 & 0.133 \\
\hline Practice Score & $9.15 \pm 2.71$ & 0.109 & \\
\hline
\end{tabular}

\section{Significant at the level of 0.05}

Table 16 depicts the Pearson correlation, as awareness score and practice score fulfill the assumption of the Pearson's correlation as data were distributed normally. There was no significant relationship between awareness score and practice score of mothers regarding health promotional measure of infants $(r=0.109, p=0.133)$.

\section{Discussion}

In concern of awareness regarding the breastfeeding the present study reveals that $100 \%$ women were aware of feeding colostrums to the child followed by $93.7 \%$ of mothers were aware about the meaning of breastfeeding. Only $35.6 \%$ mothers had awareness regarding breastfeeding. The result was also inconsistent with the findings of the study done by Koirala,S and Koirala, M [12] "Awareness and Practice of Mothers Regarding Health Promotion of Under-Five Children in Urban Slum Area of Kathmandu" revealed that $100 \%$ mothers new they had to breastfeed their infant this contradiction due to different seating. Regarding beast nutrition for $<6$ months baby $71.2 \%$ mothers were mentioned breastfeeding. Similarly only $11 \%$ mothers knew about duration of breastfeeding with complimentary feeding. Most of them 59.2\% mothers mentioned colostrums is important to prevent disease to their infants. Regarding benefit of the breast feeding $62.3 \%$ mothers revealed it provides immunity to their infants. The mean score of awareness of breastfeeding was 5.77 with standard deviation of 1.27 .

Regarding complementary feeding findings of the present study reveals that $26.7 \%$ mothers knew the meaning of complementary feeding. The result was also inconsistent with the findings of the study done by Koirala and Koirala [12]"Awareness and Practice of Mothers Regarding Health Promotion of Under-Five Children in Urban Slum Area of Kathmandu" revealed that $97.7 \%$ of mothers were aware of the complimentary feeding. This Contradiction Might be due to mothers had different education status who were attending Maternal and Child Health Clinic of Chhetrapati Kathmandu. Similarly time to start complimentary feeding $29.8 \%$ mothers mentioned from 6 months. The result also inconsistent with the findings of the study done by Koirala and Koirala [12] revealed that $75.5 \%$ mothers were aware about starting time of complimentary feeding this 


\section{International Journal of Science and Research (IJSR) ISSN: 2319-7064}

ResearchGate Impact Factor (2018): 0.28 | SJIF (2019): 7.583

contradiction might be due to different seating and $40.3 \%$ said mashed cereals should be used for complimentary feeding. Only $30.2 \%$ of mothers knew about frequency of complimentary feeding for six to eight months. Similarly 19.4\% mothers mentioned correct answered regarding frequency of food for babies of 9-12 months. Feed mashed cereals for complementary feeding while at national level only 32.3 percent of children aged 6-8 months had been fed solid foods according to DOHS annual report of Nepal [10] which is inconsistent with the study conducted by Subba SH et al. [13] found almost $40 \%$ of the mothers started complementary feeding before the recommended age of 6 months and $22.5 \%$ delayed introduction of complementary feeding beyond the recommended age. The mean score of awareness of complimentary feeding was 2.59 with standard deviation of 1.16 .

Awareness of mothers regarding immunization only $21.5 \%$ of mothers answered correctly about immunization provided for < one year baby. Regarding time to start DPT vaccine for new born $38.7 \%$ mothers mentioned within 45 days. Similarly time interval for DPT, Hep B, Hib and polio $66 \%$ mothers answered correctly. Likewise regarding meaning of immunization $53.4 \%$ mothers mentioned it gain protection from different disease. Regarding advantages of immunization $37.2 \%$ mothers revealed it prevent from all childhood disease. The result was also inconsistent with the findings of the study done by Koirala and Koirala[12] "Awareness and Practice of Mothers Regarding Health Promotion of Under-Five Children in Urban Slum Area of Kathmandu" revealed that $75.5 \%$ mothers felt importance of immunization for their children this contradiction due to different seating.

Accidental injuries are a major health problem in children. They are the most common cause of death in children under one years of age. Every year they leave many thousands permanently disabled or disfigured. Most of these accidents are preventable through increased awareness, improvements in the home environment and greater product safety. In present study awareness of mothers regarding common home accidents one third $33 \%$ mothers answered fall, ingestion injury and burn as a common home accidents for < one year baby. Similarly $42.4 \%$ mothers mentioned avoiding small piece of object in toys and other environment for prevention of ingestion injury among infants. Only $25.1 \%$ mothers mentioned keeping everything in mouth caused by developmental factors leading to ingestion injury to infant. Similarly more than half $60.7 \%$ mothers revealed do not leave the child alone for prevention of fall accidents among infants.

In practice only $34.6 \%$ started breast feeding within half an hour to one hour after birth this finding is inconsistent with the study. [14] With this finding as $57 \%$ of the mothers knew that breast feeding should be initiated within 1 hour of delivery and only $18.7 \%$ actually have initiated within the first hour of birth. This contradiction may be due to the setting which different one with another study. Another study conducted in Pokhara Nepal by Subba SH et al. [13] found only $43.5 \%$ of the mothers initiated breastfeeding within one hour of birth and $60.5 \%$ were practicing exclusive breastfeeding at 5 months, which is also incongruent with the present study. According to DOHS annual report of Nepal [10] only $31.7 \%$ of 0 to 12 month olds had been exclusively breast fed which is a slight increase on the previous year however this study found better practice $67.5 \%$ mothers provide exclusive breastfeeding to their babies this contradiction might be due to narrow setting of this study.

National Nutrition Programme Strategies to control Protein Energy Malnutrition (PEM) and improve nutrition in Nepal are: promote breast feeding within one hour of birth and avoid pre-lacteal feeding [15] however this study showed $74.07 \%$ of mothers feed honey as a pre-lactal feed which is very common practice in Hindu culture. In terms of safety practice only $15.3 \%$ done burping after feeding and $18.45 \%$ had practice of wiping the breast with clean cloth before feeding.

In actual practice only $21.4 \%$ of the mothers started complementary feeding at the age of 6 months. $27.2 \%$ feed mashed cereals for complementary feeding while at national level only 32.3 percent of children aged 6-8 months had been fed solid foods according to DOHS annual report of Nepal [15] which is consistent with the study. Similarly $42.4 \%$ mothers had been continuation of breastfeeding with complimentary feeding. The study was also consistent with findings of the study done by Koirala and Koirala [12] "Awareness and Practice of Mothers Regarding Health Promotion of Under-Five Children in Urban Slum Area of Kathmandu" revealed that only $35.5 \%$ mothers practiced on continuous breastfeeding with complimentary feeding. In this study $36.1 \%$ of the mothers had practice of washed their hands with soap and water before giving food to their children, $8.4 \%$ of the mothers even washed the utensils with boiled water and $6.1 \%$ tasted their food before feeding to the children The mean score of practice regarding complimentary feeding was 1.82 with standard deviation of 2.14 .

National Immunization Programme is a highest priority programme of Government of Nepal to reduce the under 5 mortalities. The initiative of Reaching Every Child and declaring districts as fully immunized was already initiated. The immunization Act endorsed says that every child has the right to access quality vaccines [10] Because of this policy $100 \%$ mothers had immunized their baby according to immunization schedule. Most of the (71.2\%) respondents answered correctly about action taken for baby with side effects after vaccination to prevent and manage complication. In this study immunization coverage was good $(100 \%)$ than national level 66\%[10]

Accidental injuries to infants and young children are often serious, but are largely preventable with appropriate information and safe practices. Young children are particularly vulnerable to accidents due to their innate desire to explore their world and the inability to perceive the dangers of their actions. As children learn through experience, minor injuries are inevitable but providing a safe environment can reduce the risks, coupled with close supervision and setting the limits of safety. Parents should remember that they need to maintain a constant balance between overprotecting the child on one hand and giving

\section{Volume 9 Issue 7, July 2020 www.ijsr.net}




\section{International Journal of Science and Research (IJSR) \\ ISSN: 2319-7064}

ResearchGate Impact Factor (2018): 0.28 | SJIF (2019): 7.583

him freedom in his process of learning the hazards of his environment. In current study Practice regarding accidents, $35.1 \%$ mothers do correct practice when child suffering from burn. $71.7 \%$ of the mothers didn't leave their child alone to prevent from fall accidents whereas $29.1 \%$ kept the bedside railings. Around $12.8 \%$ of the mothers didn't allow their children to go to high places. Only $45.0 \%$ mothers knew about action taken to prevent ingestion injury among infants and $81.6 \%$ mothers take correct precaution when babies are playing. Most of the $(71.7 \%)$ of mothers do not leave the child alone to prevent fall accidents among infants.

\section{Conclusion}

Based on the finding, it can be concluded that there was four-fifth poor level of awareness and where as two-third level of practice among the mothers of infant regarding health promotional measure. There was no association between awareness and practice with socio- demographic variable. There was positive correlation seen between awareness and practice score.

\section{References}

[1] Population Division, "Nepal Demographic and Health Survey 2011," Kathmandu Nepal, 2011. Accessed: Jul. 08, 2020. [Online]. Available: http://www.measuredhs.com.

[2] C. Peggyl, Infants and early childhood, childhood maintenance, 2nd editio. The CV Mosby Company, 1997.

[3] World Health Organization, "Health promotion," 2017. http://www.who.int/topics/health_promotion/en/ (accessed Jan. 17, 1017).

[4] P. Dutta, Peadiatric Nursing, Third edit. New Delhi India.: Jaypee Brothers Medical Publishers (p) LTD, 2010.

[5] Unicef, Implementing Child Rights in Early Childhood. 2006.

[6] T. Shrestha, Essential Child Health Nursing, Second. Kathmandu Nepal: Medhavi Publication, 2016.

[7] Central for disease control and preventon, "Childhood Injury Report | Child Safety and Injury Prevention," 2008. Accessed: Jul. 08, 2020. [Online]. Available: https://www.cdc.gov/safechild/child_injury_data.html.

[8] M. G. Dávila, V. P. Polanco, and L. Segura, "Global News Low Vaccination Coverage in Nepal," $A J P H$ Glob. News, vol. 108, no. Vol No.1, 2016, doi: 10.2105/AJPH.2017.304183.

[9] "Nepal Demographic and Health Survey," 2016.

[10]Department of Health services, "Annual Report 2015/2016," Kathmandu Nepal.

[11]R. H. Chapagain, "Factors affecting complementary feeding practices of Nepali mothers for 6 months to 24 months children.," J Nepal Heal. Res Counc, vol. 11, no. 24, pp. 205-7, 2013.

[12] S. Koirala and M. Koirala, "Awareness and Practice of Mothers Regarding Health Promotion of Under-Five Children in Urban Slum Area of Kathmandu," J. Inst. Med., vol. 37, no. 2, 2015, Accessed: Jul. 08, 2020. [Online]. Available: https://catalog.ihsn.org/index.php/citations/50856.

[13] S. H. Subba, T. S. Chandrashekhar, V. S. Binu, H. S.
Joshi, M. S. Rana, and S. B. Dixit, "Infant feeding practices of mothers in an urban area in Nepal," Kathmandu Univ. Med. J., vol. 5, no. 17, pp. 42-47, 2007.

[14]U. Senarath, M. J. Dibley, and K. E. Agho, "Breastfeeding practices and associated factors among children under 24 months of age in Timor-Leste.," Eur. J. Clin. Nutr., vol. 61, no. 3, pp. 387-97, Mar. 2007, doi: $10.1038 /$ sj.ejcn.1602536.

[15] Department of Health, “Annual Report," Kathmandu Nepal. Accessed: Jul. 08, 2020. [Online]. Available: https://dohs.gov.np/wpcontent/uploads/2017/06/DoHS_Annual_Report_2072_ 73.pdf. 